\title{
In vitro toxicology of respirable Montserrat volcanic ash
}

Martin R Wilson, Vicki Stone, Richard T Cullen, Alison Searl, Robert L Maynard, Kenneth Donaldson

\begin{abstract}
Objectives-In July 1995 the Soufriere Hills volcano on the island of Montserrat began to erupt. Preliminary reports showed that the ash contained a substantial respirable component and a large percentage of the toxic silica polymorph, cristobalite. In this study the cytotoxicity of three respirable Montserrat volcanic ash (MVA) samples was investigated: M1 from a single explosive event, M2 accumulated ash predominantly derived from pyroclastic flows, and M3 from a single pyroclastic flow. These were compared with the relatively inert dust $\mathrm{TiO}_{2}$ and the known toxic quartz dust, DQ12.
\end{abstract}

Methods-Surface area of the particles was measured with the Brunauer, Emmet, and Teller (BET) adsorption method and cristobalite content of MVA was determined by $x$ ray diffraction (XRD). After exposure to particles, the metabolic competence of the epithelial cell line A549 was assessed to determine cytotoxic effects. The ability of the particles to induce sheep blood erythrocyte haemolysis was used to assess surface reactivity.

Biomedicine Research Group, School of Life Sciences, Napier

University, 10 Colinton Road, Edinburgh EH10 5DT, Scotland, UK

M R Wilson

V Stone

K Donaldson

Institute of

Occupational

Medicine, 8 Roxburgh

Place, Edinburgh EH8 9SU, Scotland, UK

R T Cullen

A Searl

Department of Health, Skipton House, 80 London Road, London SE1 6LW, UK

R L Maynard

Correspondence to: Mr M R Wilson,

Biomedicine Research

Group, School of Life

Sciences, Napier University,

10 Colinton Road

Edinburgh EH10 5DT,

Scotland, UK

m.wilson@napier.ac.uk

Accepted 23 June 2000
Results-Treatment with either MVA, quartz, or titanium dioxide decreased A549 epithelial cell metabolic competence as measured by ability to reduce 3-(4,5-dimethylthiazol-2-yl)-2,5diphenyltetrazolium bromide (MTT). On addition of mannitol, the cytotoxic effect was significantly less with M1, quartz, and $\mathrm{TiO}_{2}$. All MVA samples induced a dose dependent increase in haemolysis, which, although less than the haemolysis induced by quartz, was significantly greater than that induced by $\mathrm{TiO}_{2}$. Addition of mannitol and superoxide dismutase (SOD) significantly reduced the haemolytic activity only of $M 1$, but not $M 2$ or $M 3$, the samples derived from predominantly pyroclastic flow events.

Conclusions-Neither the cristobalite content nor the surface area of the MVA samples correlated with observed in vitro reactivity. A role for reactive oxygen species could only be shown in the cytotoxicity of M1, which was the only sample derived from a purely explosive event. These results suggest that in general the bioreactivity of MVA samples in vitro is low compared with pure quartz, but that the bioreactivity and mechanisms of bio- logical interaction may vary according to the ash source.

(Occup Environ Med 2000;57:727-733)

Keywords: volcanic ash; cristobalite; surface reactivity

The stratovolcano in the Soufriere Hills on the island of Montserrat has been erupting since July 1995 and large amounts of volcanic ash have been generated due to pyroclastic flows, which began in April 1996. The first explosive event was in September 1996 followed by regular explosions from August 1997 until October 1997. A widespread deposition of ash has covered the southern half of the island and analysis of this ash has found it to contain both a substantial respirable component and an unexpectedly large percentage of the toxic silica polymorph cristobalite. ${ }^{1}$ The crystalline silica content of the fraction of ash less than $10 \mu \mathrm{m}$ generated by pyroclastic flows formed by lava dome collapse has been reported to be $10 \%-24 \%$ by weight, whereas the fraction of ash less than $10 \mu \mathrm{m}$ generated by explosive eruptions was $3 \%-6 \%$ by weight. ${ }^{1}$ Volcanic ash is known to exacerbate respiratory symptoms, ${ }^{2-4}$ and may also pose a risk of pneumoconiosis in heavily exposed populations. ${ }^{56}$ At a week long series of clinics on Montserrat in August 1997, paediatricians attended to more than 50 children a day who had exacerbations of asthma, bronchitis, and irritation of the eyes, ears, nose, and throat due to the volcanic ash. ${ }^{7}$ Previous studies with ash samples from other volcanoes have, in general, indicated that particle size and the percentage of crystalline free silica both play a crucial part in the development of respiratory diseases such as silicosis and tuberculosis. ${ }^{28}$ In vivo studies have shown that cristobalite is potentially fibrotic $^{9}$ and may also cause silicosis and cancer. ${ }^{10}$ The respirable fraction is the fraction of dust that penetrates to the alveolar region and particles that deposit with about $50 \%$ in this region are commonly in the range of 3-5 $\mu \mathrm{m}$ in aerodynamic diameter, depending on which convention is used. ${ }^{11}$ The high respirable fraction and high cristobalite content of the Montserrat volcanic ash (MVA) from the Soufriere Hills volcano indicates that it may present a hazard to human health.

Preliminary studies have indicated that the ash from pyroclastic flows contains not only a higher percentage of cristobalite, but also a greater amount of respirable particles than ash from explosive events. ${ }^{1}$

The objectives of the study were: 
(1) To investigate the in vitro toxicity of three respirable MVA samples compared with the inert dust $\mathrm{TiO}_{2}$ and the known toxic quartz dust DQ12.

(2) To find the mechanism of any toxicity by the use of inhibitors.

We examined three ash samples: M1 from a single explosive event; M2 a sample of accumulated ash from the first year of activity which was predominantly derived from pyroclastic flows; and M3 from a single pyroclastic flow event.

The effect of these particles on the metabolic competence of the human alveolar type II epithelial cell line A549 was assessed in the presence and absence of the antioxidant mannitol. We also investigated the potential of the particles to induce sheep blood erythrocyte haemolysis as a measure of ability to induce membrane damage. It has been shown that the induction of haemolysis is a useful indicator in measuring the potential cytotoxicity of mineral dusts. ${ }^{12-16}$ Finally, the mechanism by which the particles induced haemolysis was investigated with antioxidants and a chelator of metal ions.

\section{Materials and methods}

COLLECTION AND PREPARATION OF RESPIRABLE ASH SAMPLES

The MVA samples studied were derived from three sources. M1 was ash derived from a single explosive event and collected at the Montserrat Volcanic Observatory in Oldtowne in August 1997. M2 was a sample from ash which had accumulated from the beginning of the eruptions to May 1997. This sample was collected in Plymouth from an accumulation depth of $20 \mathrm{~cm}$. M3 was derived from the fallout from a single pyroclastic flow, also collected in 1997.

To remove the coarse dust component, bulk material from each of the ash samples was passed through a $2.5 \mathrm{~mm}$ mesh metal sieve. The sieved material was then carried into a cyclone, with a drop out bag attached, by compressed air from which the respirable fraction of the aerosolised ash was collected onto Whatman No 4 filter papers. In all experiments both standard DQ12 quartz ${ }^{17}$ and fine titanium dioxide (Tioxide, $\mathrm{UK}: \mathrm{TiO}_{2} ; 250 \mathrm{~nm}$ primary particle diameter) were used as comparative particles.

ANALYSIS OF RESPIRABLE ASH FRACTIONS

The specific surface area of the particles was measured with the Brunauer, Emmet and Teller (BET) nitrogen gas adsorption method. ${ }^{18}$

The cristobalite content of the volcanic ash samples was measured with $x$ ray diffraction (XRD). Samples of each ash were mixed with corundum and the cristobalite contents of each calculated from relative intensity of the cristobalite and corundum peaks in the samples compared with those from calibration standards composed of a mixture of cristobalite, corundum, and an amorphous borate phase. ${ }^{19}$

Ash samples were prepared for the analysis of distribution of particle size by suspension in filtered water and deposition on polycarbonate filters. Samples of the filters were carbon coated and transferred to copper grids for analysis with a transmission electron microscope (TEM). The particle size distribution of the ash samples and that of the control particles DQ12 and $\mathrm{TiO}_{2}$ was assessed with an image analysis programme.

EFFECT ON EPITHELIAL CELL METABOLISM

ASSESSED BY THE MTT ASSAY

The human A549 lung epithelial type II cell line $^{20}$ (American Type culture collection) was grown to confluence in Dulbecco's modified Eagle's medium (DMEM; Life Technologies, UK) with $10 \%$ heat inactivated foetal calf serum (FCS; Life Technologies, UK), penicillin-streptomycin (0.06 Units/ml and 30 $\mu \mathrm{g} / \mathrm{ml}$ respectively; Life Technologies, UK) and L-glutamine (2 mM; Life Technologies, UK). Cultures were incubated in an atmosphere of $5 \% \mathrm{CO}_{2}$ at a temperature of $37^{\circ} \mathrm{C}$.

Cytotoxicity was assessed by the ability of cells to reduce the tetrazolium salt $3-(4,5-$ dimethylthiazol-2-yl)-2,5-diphenyltetrazolium bromide (MTT) ${ }^{21}$ Before exposure to particles, cells were removed from the flask with trypsin and centrifuged at $900 \mathrm{~g}$ for 2 minutes. The cell pellet was resuspended in DMEM ( $10 \%$ FCS), and the viability was assessed by the ability of cells to exclude $1 \%$ trypan blue (Sigma, UK). Cells were then seeded into 96 well plates (Helena Biosciences, UK) at a density of $1 \times 10^{5}$ cells $/ \mathrm{ml}$ in DMEM ( $10 \%$ FCS), $200 \mu \mathrm{l}$ per well and incubated in an atmosphere of $5 \% \mathrm{CO}_{2}$ at $37^{\circ} \mathrm{C}$ for 24 hours.

Suspensions of the MVA samples, DQ12, and $\mathrm{TiO}_{2}$ were made in DMEM (10\% FCS) with or without mannitol (Sigma, UK) at a final concentration of $2 \mathrm{mM}$, which were mixed by brief vortexing followed by sonication for 10 minutes. A series of dilutions of each of the particles were made in DMEM $(10 \% \mathrm{FCS})$ to give final concentrations ranging from 16.5$1000 \mu \mathrm{g} / \mathrm{ml}$. The medium was removed from the cells and replaced with either a suspension of particles or fresh DMEM (10\% FCS) before incubating at $37^{\circ} \mathrm{C}, 5 \% \mathrm{CO}_{2}$ for either 24 or 48 hours.

Immediately after the cells had been treated with particles, MTT (Sigma, UK) was dissolved in DMEM (10\% FCS) at $0.5 \mathrm{mg} / \mathrm{ml}$ and filter sterilised with a $0.2 \mu \mathrm{m}$ filter (Whatman, UK). The cell medium and suspensions were then replaced with $200 \mu \mathrm{l}$ per well of the MTT solution. The cells were incubated with the MTT solution for 4 hours at $37^{\circ} \mathrm{C}, 5 \% \mathrm{CO}_{2}$ before removing the medium and replacing with $150 \mu \mathrm{l}$ of isopropanol/0.04 $\mathrm{M} \mathrm{HCl}$ (Sigma, UK/ BDH, UK). To prevent interference due to the presence of the particles, the 96 well plates were centrifuged (700 $g$ for $15 \mathrm{~min}$ utes) and $100 \mu$ l supernatant transferred from each sample to a new 96 well plate to be read at $550 \mathrm{~nm}$ (MRX plate reader; Dynatech Labs, $\mathrm{UK})$

HAEMOLYTIC EFFECTS OF MONTSERRAT VOLCANIC ASH

Haemolytic activity of the particles was measured with a $10 \%$ erythrocyte solution 
using a modified method from Razzaboni et $a l .^{22}$ Sheep erythrocytes were obtained from the Scottish Antibody Production Unit (Carluke, UK) and were washed twice in $0.9 \%$ sodium chloride solution (Baxter, UK) and centrifuged at $90 \mathrm{~g}$ for 5 minutes. The erythrocyte pellets were resuspended and diluted in $0.9 \%$ sodium chloride solution to give a $10 \%$ erythrocyte preparation. Suspensions of MVA, along with DQ12 and $\mathrm{TiO}_{2}$, were prepared in $0.9 \%$ sodium chloride solution, mixed by vortexing and sonicated for 10 minutes. The particle suspensions $(150 \mu \mathrm{l})$ were mixed in triplicate with $75 \mu \mathrm{l}$ of $10 \%$ erythrocyte preparation. Sodium chloride solution $(0.9 \%)$ was used as a negative control, and the positive control was $0.1 \%$ Triton $\mathrm{X}-100$ (Sigma, UK) in $0.9 \%$ sodium chloride solution. The mixtures were incubated at room temperature for 10 minutes on an orbital plate shaker before centrifugation at $700 \mathrm{~g}$ for 5 minutes. The supernatants $(100 \mu \mathrm{l})$ from each sample were transferred to a 96 well plate and the optical densities read at $540 \mathrm{~nm}$ (MRX plate reader; Dynatech Labs, UK).

\section{FACTORS RESPONSIBLE FOR HAEMOLYSIS}

To find the possible mechanisms by which the particles induced haemolysis, three antioxidants and an iron chelator were each added to suspensions of MVA, DQ12, and $\mathrm{TiO}_{2}$ in separate experiments. The antioxidants used were mannitol (4 $\mathrm{mM}$ final concentration), SOD (1000 Units final concentration) and nacystelin (500 $\mu \mathrm{M}$ final concentration). To test the specificity of the superoxide/SOD reaction, heat inactivated SOD $\left(90^{\circ} \mathrm{C}\right.$ for 5 minutes) was also added to the erythrocyte and particle mixture to give a final concentration of approximately $210 \mu \mathrm{g} / \mathrm{ml}$ (equivalent to 1000 Units SOD).

To investigate the role of transition metals in the haemolytic potential of the particles, the particles were incubated with deferoxamine mesylate (10 mM final concentration; Sigma, UK) for 2 hours in a shaking water bath at $37^{\circ} \mathrm{C}$ before exposure to erythrocytes.

\section{STATISTICAL ANALYSIS}

All data are expressed as mean (SEM). The number of observations for each experiment was nine except where stated. The data were analysed by one way analysis of variance (ANOVA) with Tukey's multiple comparison test, and $\alpha<0.05$ was considered significant for all comparisons.

\section{Results}

PHYSICAL CHARACTERISATION OF PARTICLES All three respirable MVA samples possessed similar surface areas which were comparable with $\mathrm{TiO}_{2}$, but less than that of DQ12 (table 1).

Analysis of the respirable MVA samples with XRD showed that they consisted mainly of plagioclase feldspar of roughly andesine composition. Within the context of these ash samples, the measurment of cristobalite by XRD proved difficult due to coincidence of the major plagioclase peak with that representing the cristobalite peak at $22.0^{\circ} 2 \theta$. The cristobalite content of the MVA samples was assessed and
Table 1 Physical characteristics of three respirable samples of Montserrat volcanic ash (M1, M2, and M3), DQ12 quartz, and $\mathrm{TiO}$

\begin{tabular}{|c|c|c|c|}
\hline Particle & $\begin{array}{l}\text { Surface area } \\
\left(\mathrm{m}^{2} / g\right)\end{array}$ & $\begin{array}{l}\text { Cristobalite } \\
\text { content (\%) }\end{array}$ & $\begin{array}{l}\text { Proportion of } \\
\text { particles }<3 \mu \mathrm{m} \\
\text { in diameter (\%) }\end{array}$ \\
\hline M1 & 6.59 & 2.5 & 91.8 \\
\hline M2 & 7.94 & 11.1 & 86.4 \\
\hline M3 & 5.89 & 5.8 & 86.2 \\
\hline DQ12 & 10.10 & Not measured & 99.9 \\
\hline $\mathrm{TiO}_{2}$ & 6.68 & Not measured & 100 \\
\hline
\end{tabular}

corrected for plagioclase by measuring the peak intensity at two other plagioclase peaks $\left(27.8^{\circ} 2 \theta\right.$ and $\left.82.1^{\circ} 2 \theta\right)$ and calculating the intensity at $22.0^{\circ} 2 \theta$ that could be attributed to plagioclase from tabulated ratios of the relative intensity of the three peaks in an ideal andesite sample. After correction, M2 was found to contain the largest percentage of cristobalite compared with M3 and M1 (table 1).

The size distribution of the three respirable MVA particle samples were comparable with each other with the largest percentage of particles by number in the range of 0.1 to $0.3 \mu \mathrm{m}$ (fig 1). Within this size range, $M 1$ was found to contain the largest percentage of particles at $29 \%$ compared with M3 at $21.9 \%$, and M2 at $19 \%$. The DQ12 and $\mathrm{TiO}_{2}$ contained $26.2 \%$ and $31.9 \%$ of particles in this range respectively. There was however a "tail" of larger particles in the three MVA samples which would be anticipated to impact on the surface area. However, as already noted, there was no marked differences in surface areas between the MVA samples, DQ12 and $\mathrm{TiO}_{2}$.

EFFECT OF MONTSERRAT VOLCANIC ASH SAMPLES ON A549 CELL METABOLISM OF MTT

After treatment of the A549 cells for 24 hours, all of the particles tested induced a dose dependent decrease in MTT metabolism, reaching a maximal effect at $500 \mu \mathrm{g} / \mathrm{ml}$ (fig 2).

The $\mathrm{TiO}_{2}$ sample was found to be less cytotoxic than either the MVA samples or DQ12 compared with controls at the lower doses tested-for example, $125 \mu \mathrm{g} / \mathrm{ml}, \quad \mathrm{p}<0.001$ (results expressed as MTT absorbance as a percentage of untreated cells); mean (SD) control $=100 \% \quad(4.61 \%) ; \quad M 1=72.25 \% \quad(5.11 \%)$; M2 $=74.18 \%(5.76 \%) ; M 3=72.29 \%(6.17 \%)$; DQ12 $=67.33 \%(4.93 \%)$; and $\mathrm{TiO}_{2}=79.44 \%$ (5.19\%). However, at higher doses tested there were no significant differences between any of the particles tested.

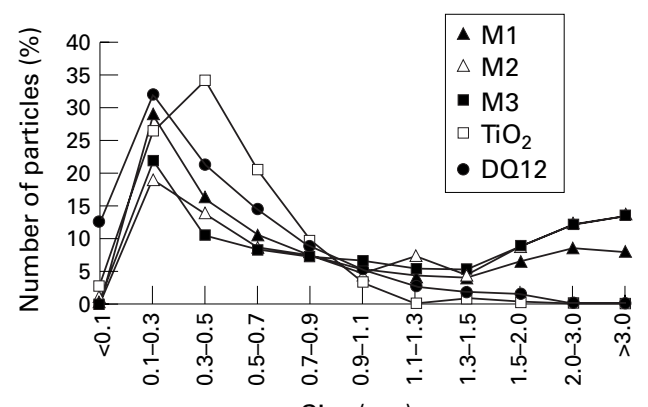

Size $(\mu \mathrm{m})$

Figure 1 The proportional particle size distribution as assessed by transmission electron microscopy image analysis. 
The effect of the antioxidant mannitol on the inhibition of A549 metabolic function by particles was also investigated. At 24 hours all of the particles tested in the presence of mannitol $(2 \mathrm{mM})$ continued to induce a dose dependent decrease in metabolic reduction of MTT, compared with the control, again reaching a maximal effect at $500 \mu \mathrm{g} / \mathrm{ml}$ (fig 2). However, in the presence of mannitol, $\mathrm{TiO}_{2}$ and DQ12 were significantly less cytotoxic than either M2 or M3 (500 $\mu \mathrm{g} / \mathrm{ml} ; \mathrm{p}<0.001$; fig 2). This was also reflected at the lowest concentration tested, $62.5 \mu \mathrm{g} / \mathrm{ml}$, where only M2 and M3 were able to significantly decrease MTT metabolism compared with the controls ( $\mathrm{p}<0.001$ (results expressed as MTT absorbance as a percentage of untreated cells); mean (SD) control $=79.29 \%(2.16 \%) ; \mathrm{M} 1=74.65 \%$ $(5.08 \%) ; \mathrm{M} 2=63.13 \%(4.80 \%) ; \mathrm{M} 3=59.97 \%$ $(2.00 \%) ; \quad$ DQ $12=68.19 \% \quad(2.59 \%)$ and $\mathrm{TiO}_{2}=73.63 \%(2.77 \%)$.

Similar results were also found at 48 hours (data not shown).

HAEMOLYTIC ACTIVITY OF MONTSERRAT ASH SAMPLES

A dose dependent increase in erythrocyte haemolysis was found with all particle types tested (fig 3). The DQ12 had the greatest haemolytic ability $(109 \%(1.5 \%)$ haemolysis at

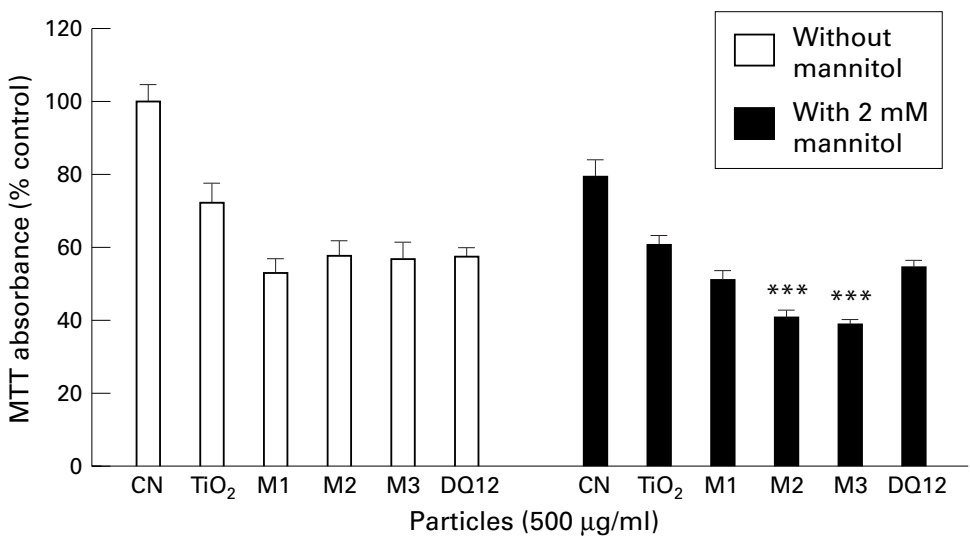

Figure 2 The effect of a $500 \mu \mathrm{g} / \mathrm{ml}$ dose of $\mathrm{MVA}$ samples, $\mathrm{DQ} 12$ and $\mathrm{TiO}_{2}$, in the presence or absence of the antioxidant mannitol ( $2 \mathrm{mM})$, on the metabolism of MTT by A549 cells after 24 hours. Results are expressed as a percentage of untreated cells. $(* * *$ $p<0.001 ; M 2$ or $M 3$ v DQ12 or $\mathrm{TiO}_{2}$.)

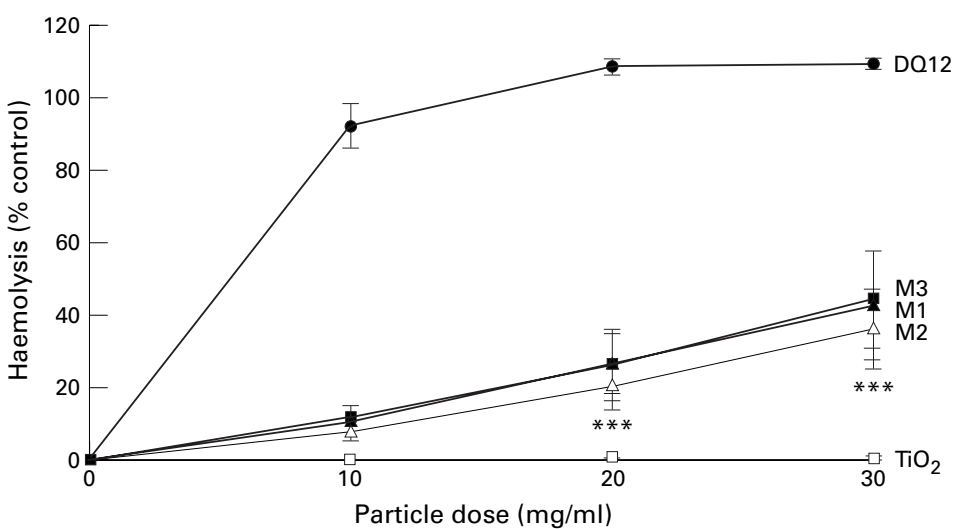

Figure 3 The effect of an increasing particle concentration of $M V A$ samples, DQ12, and $\mathrm{TiO}_{2}$ on the haemolysis of sheep blood erythrocytes. Results are expressed as percentage haemolysis compared with both negative $(0.9 \%$ sodium chloride solution) and positive $(0.1 \%$ Triton $\mathrm{X}-100)$ controls. $\left(* \star * p<0.001\right.$; haemolysis induced by $\mathrm{TiO}_{2} v$ that induced by the MVA samples.)

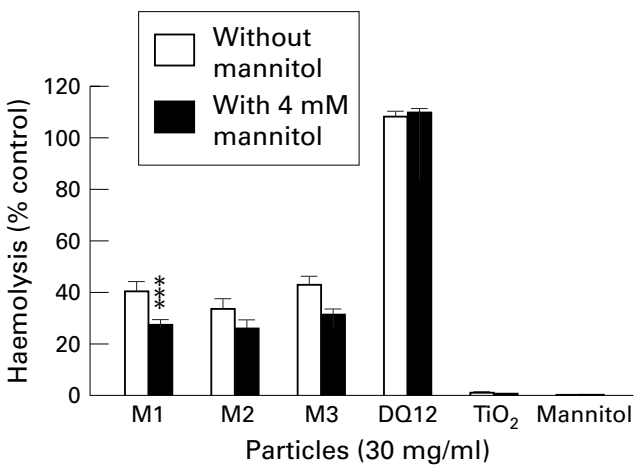

Figure 4 Sheep blood erythrocyte haemolysis induced by $30 \mathrm{mg} / \mathrm{ml}$ concentration of particles in the presence or absence of $4 \mathrm{mM}$ mannitol $(\star \star \star p<0$.001).

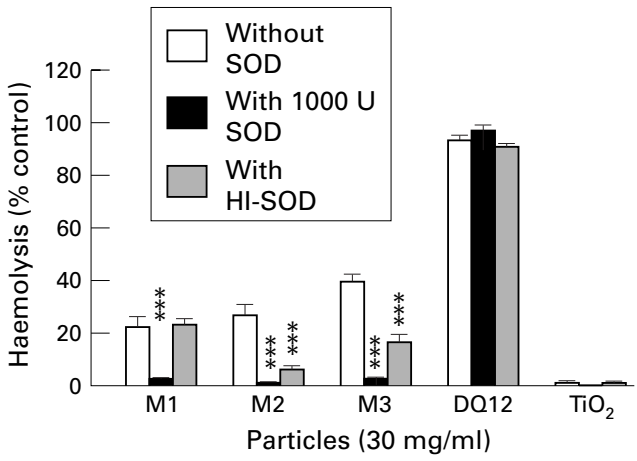

Figure 5 Sheep blood erythrocyte haemolysis induced by $30 \mathrm{mg} / \mathrm{ml}$ concentration of particles with the additions of 1000 Units $S O D$ and $210 \mu \mathrm{g} / \mathrm{ml}$ heat inactivated SOD (HI-SOD). ( $* * * p<0.001$ haemolysis induced by the MVA samples only $v$ that induced after the addition of either SOD or HI-SOD.)

$30 \mathrm{mg} / \mathrm{ml})$, with $\mathrm{TiO}_{2}$ having the least $(0.75 \%$ $(0.5 \%)$ haemolysis at $30 \mathrm{mg} / \mathrm{ml})$. The three MVA samples had a similar dose dependent increase in haemolysis which although lower than the DQ12 haemolysis, was significantly higher than $\mathrm{TiO}_{2}$ at both 20 and $30 \mathrm{mg} / \mathrm{ml}$ ( $\mathrm{p}<0.001$; fig 3 ).

The addition of $4 \mathrm{mM}$ mannitol slightly decreased the haemolysis induced by all the MVA samples; however, this was only significant with M1 ( $\mathrm{p}<0.001$; fig 4$)$.

The SOD (1000 Units) induced the greatest inhibition of haemolysis found with any antioxidant tested $(p<0.001$; fig 5$)$. To find whether these effects were due to the specific enzymatic activity of SOD or due to a protein coating effect, a solution of 1000 Units SOD (approximately $210 \mu \mathrm{g} / \mathrm{ml}$ ) was heat inactivated, as described previously, and added to the reaction solutions. The heat inactivated SOD (HI-SOD) was also found to cause a significant inhibition of haemolysis induced by both M2 and M3 ash samples ( $p<0.001$; fig 5), but not that induced by M1.

The addition of $500 \mu \mathrm{M}$ nacystelin did not cause a significant decrease in the haemolysis induced with any of the particles tested (table 2).

Also, chelation of metals by deferoxamine (10 $\mathrm{mM}$ ) did not inhibit the haemolysis induced by any of the MVA samples (table 2). By contrast, deferoxamine seemed to increase the haemolytic ability of DQ12, but this was not found to be significant. 
Table 2 Erythrocyte haemolysis induced by $30 \mathrm{mg} / \mathrm{ml}$ of particles in the prescence or absence of either $10 \mathrm{mM}$ deferoxamine or $500 \mu \mathrm{M}$ nacystelyn (results expressed as mean (SEM) percentage haemolysis by comparison with both negative $(0.9 \% \mathrm{NaCl})$ and positive (Triton $X-100)$ controls)

\begin{tabular}{lrrrr}
\hline & $\begin{array}{l}\text { Without } \\
\text { deferoxamine }\end{array}$ & $\begin{array}{l}\text { With 10 mM } \\
\text { deferoxamine }\end{array}$ & $\begin{array}{l}\text { Without } \\
\text { nacystelyn }\end{array}$ & $\begin{array}{l}\text { With } 500 \mu M \\
\text { nacystelyn }\end{array}$ \\
\hline $\mathrm{M} 1$ & $7.61(0.58)$ & $6.59(1.20)$ & $38.79(4.51)$ & $35.60(2.89)$ \\
$\mathrm{M} 2$ & $11.53(0.88)$ & $11.15(0.54)$ & $33.61(2.02)$ & $28.83(5.52)$ \\
$\mathrm{M} 3$ & $15.82(0.76)$ & $9.60(0.93)$ & $36.42(2.81)$ & $36.95(4.86)$ \\
$\mathrm{DQ} 12$ & $86.47(4.01)$ & $103.35(1.56)$ & $87.45(2.29)$ & $80.71(5.94)$ \\
$\mathrm{TiO}_{2}$ & $0.29(0.08)$ & $1.84(0.14)$ & $-0.11(0.24)$ & $0.09(0.20)$ \\
Deferoxamine & & $0.63(0.20)$ & & $0.63(0.35)$ \\
Nacystelyn & & & & \\
\hline
\end{tabular}

\section{Discussion}

The reported health effects of volcanic ash vary between different volcanoes. For example, the prevalence of respiratory symptoms of exposed people inhabiting five towns around the crater of Mount Sakurajima in Japan were found to be minimal. ${ }^{23}$ Analysis of this ash showed a crystalline silica content which was almost negligible and that the major component of the ash particulate was non-respirable. ${ }^{24}$

By contrast, a fourfold increase in emergency room visits for patients with asthma and a twofold increase for patients with bronchitis followed the 1980 eruption of Mount St Helens in the United States. ${ }^{2}$ Analysis of this ash showed a crystalline silica content of between $3 \%$ and $7.2 \%^{5625}$ of which $4.2 \%$ was cristobalite. ${ }^{56}$ The ash particulates were found to be around $90 \%{ }^{26}$ and $99 \%$ respirable (defined as less than $10 \mu \mathrm{m}$ in diameter in this study). ${ }^{6}$

In the present study collection of the MVA samples and their subsequent analysis showed that M2 (accumulated ash) contained 11.1\% cristobalite, which was twofold greater than that of the M1 and M3 samples, and threefold greater than the pathogenic Mount St Helens ash.

The particle size distributions of the respirable MVA samples were comparable with each other, with M1 (the explosive ash sample) being slightly finer than M2 (the accumulated ash sample) or M3 (the ash sample from a single pyroclastic flow). As a consequence, the surface areas of the three samples were also found to be similar. These data correlated well with their haemolytic ability in that the three MVA samples all induced a dose dependent increase in haemolysis inducing between 36\% and $44 \%$ haemolysis at the highest dose. These data further correlate well with those from ash particles from the Mount St Helens eruptions which were found to be significantly haemolytic and that the ash with the greatest surface area also possessed the greatest ability to induce haemolysis. ${ }^{16}$

The addition of $4 \mathrm{mM}$ mannitol significantly decreased the haemolysis induced by the M1 sample, but not that induced by M2 or M3 . However, in general, the effects of mannitol on the haemolysis induced by all three MVA ash samples was relatively small indicating that hydroxyl radical production did not play a major part in the haemolytic ability of these particles. Nacystelyn, a lysinated derivative of the glutathione precursor $\mathrm{N}$-acetylcysteine, was also used as an antioxidant in the haemo- lysis assay. Nacystelyn did not decrease the haemolytic ability of any of the particles tested which again would suggest that free radical production was not a major component of the haemolytic potential of these particles, or that nacystelyn is unsuitable as an erythrocyte antioxidant within cells.

With the addition of 1000 Units SOD (approximately equivalent to $210 \mu \mathrm{g} / \mathrm{ml}$ ), a significant decrease was found in the haemolytic ability of the MVA samples, but not with the pure silica sample of DQ12. These data correlate with those of a study by Razzaboni et a ${ }^{2}$ where haemolysis induced by pure silica could not be decreased with a dose range of SOD from 10 to $300 \mu \mathrm{g} / \mathrm{ml}$. From these results alone it would seem that most erythrocyte membrane damage caused by the ash samples was due to the production of superoxide. However, with such a large concentration of SOD and therefore protein, the decrease in haemolysis could have been due to the particle coating effect of the SOD protein. To find whether the decrease in haemolysis was due to either a specific dismutation of superoxide, or protein coating of particles, a non-specific enzyme with similar structure to SOD was sought. A bovine cathepsin B precursor was identified as having a similar molecular weight and tertiary structure to SOD, however, this is a protease and would therefore have been unsuitable for use in the haemolysis assay. Despite the limitations of heat inactivation-such as disruption of tertiary structure - a heat inactivated protein solution of SOD was used (HI-SOD). The haemolysis induced by M1 was inhibited by SOD, but not by HI-SOD suggesting that the decrease in haemolysis was in fact due to a specific dismutation of the superoxide radical produced by the M1 sample in the reaction solution. However, the haemolytic ability of M2 and M3 was significantly decreased with the addition of both SOD and HI-SOD. Subsequently these results suggested that the decrease in haemolytic ability found with M2 and M3 was due to protein coating of particles and not a specific dismutation of superoxide. Also, these results indicate differences in the mechanisms of the biological reactivity of these particles in accordance with their origin.

The role of particle surface metal ions in the haemolytic activity found for the MVA samples, DQ12, and $\mathrm{TiO}_{2}$ was investigated by addition of the metal ion chelator deferoxamine $(10 \mathrm{mM})$. After a 2 hour preincubation of deferoxamine and particles, no significant decrease in haemolytic ability of the particles was found. This would imply that metal ions are not a major factor in the haemolytic activity or that the available metal ions present in the MVA samples were minimal.

It should be noted that the percentage haemolysis on exposure to the MVA samples in these latter experiments were lower than found in earlier parts of this study. Increased red cell fragility in aging erythrocytes is very likely to explain these results. These differences in observed haemolysis could also be due to using a percentage solution of sheep blood erythrocytes as opposed to a specific cell number. 
In this study all of the MVA samples, DQ12, and $\mathrm{TiO}_{2}$ induced a dose dependent decrease in the A549 metabolism of MTT which would suggest that the metabolic inhibition found was independent of particle composition. There was, however, significantly less toxicity caused by $\mathrm{TiO}_{2}$ than DQ12 at a lower dose. With the addition of the antioxidant mannitol, the cytotoxic effect induced by $\mathrm{M} 1, \mathrm{DQ} 12$, and $\mathrm{TiO}_{2}$ was significantly less. Inhibition by mannitol implies involvement of hydroxyl radicals and therefore in this in vitro mechanism M1 seems to have its effect through this reactive intermediate. The metabolic inhibition induced by the addition of M2 and M3 could not be reduced by the addition of mannitol. These differences in the MVA samples could possibly be related to the origin of the volcanic ash, of which M1 is the only ash sample derived from a purely explosive event.

In the MVA samples we have calculated a maximum cristobalite content of $11.1 \%$ in sample M2, which is most likely present within a complex mineral matrix containing elements - such as aluminium - which have the potential to reduce the reactivity of silica. We note that these cristobalite concentrations are slightly lower than the overall crystalline silica contents reported by Baxter et al (1999). ${ }^{1}$ Studies documenting the relation between silica haemolysis and cytotoxicity have, in general, used pure silica samples. With the interventions we have used in our experimental systems, significantly decreasing changes in reactivity were only found in the M1 ash sample. The M1 was derived from a single explosive event compared with M2 from predominantly pyroclastic flow sources, and M3 from a single pyroclastic flow. As pyroclastic flow ash is known to be physically and chemically different from explosive ash, ${ }^{1}$ this may explain the in vitro differences between M1 compared with M2 and M3.

The haemolysis assays in this study were not used to understand the pathophysiology of the particles, as the large doses and inappropriate target cells preclude this, but solely to assess the surface reactivity of the mixed mineral ash samples in direct comparison with the pure silica sample of DQ12 and the relatively inert $\mathrm{TiO}_{2}$. With the haemolysis of sheep erythrocytes as a model, we consistently found that the ash samples had a surface reactivity lower than that of DQ12, however, in all experiments this surface reactivity was significantly greater than an equal surface area dose of $\mathrm{TiO}_{2}$. Erythrocyte membrane damage by the MVA samples was largely through a mechanism that did not involve oxidative stress, except for M1. The haemolytic effect of $M 1$, after addition of SOD or HI-SOD, was complex in that it was SOD

Table 3 Summary of inhibitor studies with particles

\begin{tabular}{llllll}
\hline & $M 1$ & $M 2$ & $M 3$ & $D Q 12$ & $\mathrm{TiO}_{2}$ \\
\hline Haemolytic activity & + & + & + & ++++ & - \\
$\begin{array}{l}\text { Hydroxyl radical involved in haemolysis } \\
\text { Superoxide anion involved in haemolysis }\end{array}$ & + & -+ & - & - & - \\
$\begin{array}{l}\text { Hydroxyl radical involved in decreased } \\
\text { epithelial cell metabolism }\end{array}$ & ++ & - & - & - & - \\
\hline
\end{tabular}

inhibitable-that is, driven by superoxide anions, but not reduced by the coating effect of HI-SOD

In conclusion, the approach taken here was to use the highly pathogenic DQ12 quartz and the non-pathogenic dust $\mathrm{TiO}_{2}$ as benchmarks for the potential pathogenicity of the MVA samples. The three different MVA samples were of similar size and surface area to DQ12 and $\mathrm{TiO}_{2}$. All three ash samples were significantly more haemolytic than $\mathrm{TiO}_{2}$, but much less so than DQ12. Inhibitor studies are summarised in table 3 and show that there was some evidence for the involvement of superoxide anion in the haemolytic activity of some of the ash samples. From the benchmarking we anticipate that the MVA samples would have much less potential to cause lung injury than quartz but slightly more than $\mathrm{TiO}_{2}$ and that the origin of the MVA samples may determine differences in reactivity. Whether the increased activity of MVA compared with $\mathrm{TiO}_{2}$ is of sufficient magnitude to be detectable in a plausible in vivo exposure will only be answered by experiment. Further research into the toxicology of an increased range of Montserrat volcanic ash samples is warranted to ensure that representative material is assessed for toxicity.

We acknowledge the expert assistance of Dr Colin Mitchell. KD is the British Lung Foundation/Transco Fellow in air pollution is the British Lung Found
and respiratory health.

1 Baxter PJ, Bonadona C, Dupree R, et al. Cristobalite in volcanic ash of the Soufriere Hills Volcano, Montserrat, British West Indies. Science 1999;283:1142-5.

2 Baxter PJ, Ing R, Falk H, et al. Mount St Helens eruptions: the acute respiratory effects of volcanic ash in a north American community. Arch Environ Health 1983;38:13843.

3 Glaser AN. The global effects of volcanic eruptions on human health and agriculture. Fournal of Agromedicine 1996;3:31-43

4 Malilay J, Real MG, Vanegas AR, et al. Public health surveillance after a volcanic eruption: lessons from Cerro Negro, Nicaragua, 1992. Bull Pan Am Health Organ 1996;30:21826.

5 Green FHY, Vallyathan V, Mentnech MS, et al. Is volcanic ash a pneumoconiosis risk? Nature 1981;293:216-17.

6 Vallyathan V, Mentnech MS, Tucker JH, et al. Pulmonary vallyathan V, Mentnech MS, Tucker JH, et al. Pulmonary
response to Mount St Helens' volcanic ash. Environ Res response to Mount

7 Johnstone A. Heat and dust. Nursing Times 1997;93:12-13.

8 Seaton A. Chapter 12: Silicosis. In: Morgan WKC, Seaton A, eds. Occupational lung diseases. Philadelphia: Saunders, 1995:222-67.

9 Hemenway DR, Absher MP, Trombley L, et al. Comparative clearance of quartz and cristobalite from the lung. Am Ind Hyg Assoc F 1990;51:363-9.

10 International Agency for Research on Cancer. IARC monographs on the evaluation of carcinogenic risks to humans. Silica, some silicates, coal dust and para-aramid fibrils. Lyon: IARC, $1997 ; 68$.

11 Vincent JH. Chapter 9: The measurement of workplace aerosols. In: Morgan WKC, Seaton A. Occupational lung diseases. Philadelphia: Saunders, 1995:158-81.

12 Harington JS, Miller K, Macnab G. Hemolysis by asbestos. Environ Res 1971;4:95-117.

13 Hefner RE, Gehring PJ. A comparison of the relative rates of hemolysis induced by various fibrogenic and nonfibrogenic particles with washed rat erythrocytes in vitro. Am Ind Hyg Assoc f 1975;36:734-40.

14 Nolan RP, Langer AM, Harington JS, et al. Quartz hemolysis as related to its surface functionalities. Environ Res 1981;26:503-20.

15 Potts WJ, Lederer TS, Gehring PJ. Hemolysis of washed rat erythrocytes in vitro by dust particles. Am Ind Hyg Assoc f 1978;39:497-502

16 Vallyathan V, Mentnech MS, Stettler LE, et al. Mount St Helens' volcanic ash: hemolytic activity. Environ Res 1983; 30:349-60.

17 Robock K. Standard quartz DQ12 <5 $\mu \mathrm{m}$ for experimental pneumoconiosis research projects in the Federal Republic of Germany. Ann Occup Hyg 1973;16:63-6.

18 Brunauer S, Emmet PH, Teller E. Adsorption of gases in multi-molecular layers. Fournal of the American Chemical Society 1938;60:309-19. 
19 Chung FH. Quantitative interpretation of $x$ ray diffraction patterns of mixtures. I. Matrix flushing method for quantitative multicomponent a
lography 1974;7:519-25.

20 Lieber M, Smith B, Szakal A, et al. A continuous tumorcell line from a human lung carcinoma with properties of type II alveolar epithelial cells. Int $\mathcal{F}$ Cancer 1976;17:62-

21 Mosmann T. Rapid colorimetric assay for cellular growth and survival: application to proliferation and cytotoxicity assays. F Immunol Methods 1983;65:55-63.

22 Razzaboni BL, Bolsaitis P. Evidence of an oxidative mechanism for the hemolytic activity of silica particles. Environ Health Perspect 1990;87:337-41.
23 Yano E, Yokoyama Y, Nishii S. Chronic pulmonary effects of volcanic ash: an epidemiologic study. Arch Environ Health volcanic ash: an

24 Yano E, Yokoyama Y, Higashi $\mathrm{H}$, et al. Health effects of volcanic ash: a repeat study. Arch Environ Health 1990;45:36773

25 Dollberg DD, Bolyard ML, Smith DL. Evaluation of physical health effects due to volcanic hazards: crystalline silica in Mount St Helens volcanic ash. Am F Public Health 1986; 76(suppl):53-8.

26 Fruchter JS, Robertson DE, Evans JC, et al. Mount St Helens ash from the 18 May 1980 eruption: chemical, physical, 1116-25.

\section{Open reviewing}

Many journals, including the BMJ, have moved to a system of open reviewing, whereby authors know the names of reviewers of their papers. Research has shown that named reviews, although not of better quality than anonymous reviews, are not of worse quality either. Therefore in the interests of transparency, it seems fair to let authors know who has reviewed their paper. At Occupational and Environmental Medicine we have considered the issue carefully. There are some concerns that reviewers, especially those who are more junior, might feel intimidated and not wish to make negative comments about papers submitted by senior people in the field. On the other hand, some reviewers might hide behind the cloak of anonymity to make unfair criticisms so as to reduce the chances of publication by rivals. We have decided to introduce initially a system of open reviewing if the reviewers agree explicitly. So when a reviewer is sent a paper, he or she is asked to indicate whether we can disclose their name or not when sending the authors their comments. We will be monitoring this to see how many of our reviewers are happy to be named. If it is most of them, we will move to a system of open reviewing as the norm, with a possible "opt out" clause for reviewers. 